\title{
Reiki as nursing care to increase self-esteem, improve family well-being and decrease the consumption of alcohol, tobacco and marijuana in young adults
}

\section{Introduction}

The global trends reflect a general increase in the use of alcohol and illegal drugs, this increase is among the younger sectors of the population, especially street children, indigenous youth and marginalized adolescents. ${ }^{1}$ The person is forming his personality within the family environment, which influences the formation of selfesteem as values, rules and customs are incorporated, it is necessary to mention that the personality is also formed from the thoughts and perceptions that society has of it and above all of personal value. ${ }^{2}$ The relationships between self-esteem, family system and drug use create a concern because it is highlighted that the individual who has low self-esteem can be a victim who takes refuge in drugs and thus improve their sense of worth.

Each person has an energy field which is affected if the energy field of the environment is unbalanced, it should be noted that some of the manifestations that the person presents when seeing his unbalanced energy field is low self-esteem and this will lead to a negative vicious circle, low self-esteem-lack of family well-being-low self-esteemdrug use.

So the research question arises: Is Reiki effective as nursing care to increase self-esteem, improve family well-being and decrease the consumption of alcohol, tobacco and marijuana in the young adult in the state of Colima?

\section{Methodology}

A quantitative, co-relational and applied study was carried out; the selection of the participants was by men who consumed alcohol, tobacco and marijuana who lived in Colonia Griselda Álvarez in Cuauhtémoc, Colima; Four instruments were made. The study is considered of minimum risk taking as a frame of reference the stipulated in chapter I article 17 relative to the ethical aspects of investigation with human beings of the Regulation of the General Law of Health in the matter of investigation, ${ }^{3}$ in turn they respected the ethical considerations of the Declaration of Helsinki, ${ }^{4}$ followed the provisions established by the General Health Law in article 100.

\section{Results}

The 23 young adults reported being workers (30.4\%), employees (30.4\%), singles (73.9\%), with catholic religion (91.3\%), upon knowing the profile of the young adult and determining that the age of beginning of consumption of alcohol was at 13.43 years, that the age of onset of tobacco consumption was at 10.65 years, and of marijuana at 9.39 years.

When applying the descriptive statistics in the self-esteem variable, it was found that there is an increase in it after applying Reiki; because
Volume 3 Issue 2 - 2019

\author{
Rafael Rivera Valdovinos,' Leticia Casique \\ Casique, ${ }^{2}$ Alicia Alvarez Aguirre ${ }^{2}$ \\ 'Docente, Universidad Autonoma de Colima y Jefe de \\ Enfermeras del Hospital De Colima, México \\ ${ }^{2}$ Docente e Investigadora, Universidad de Guanajuato, México
}

Correspondence: Leticia Casique Casique, Docente e Investigadora, Universidad de Guanajuato, México, Email leticiacc_2004@yahoo.com.mx

Received: February 01, 2019 | Published: March 19, 2019

the young adult mentioned that he has no difficulty talking to other people (pre $=39.1 \%$ and post $=78.3 \%$ ), that he would not change many things about $\operatorname{him}$ ( $\mathrm{pre}=30.4 \%$ and post $=26.1 \%$ ), he gets angry easily at home (pre $=69.6 \%$ and post $=60.9 \%$ ), the family of the young adult if he takes into account his feelings (pre $=60.9 \%$ and post $=69.6 \%$ ), does not give up easily (pre $=65.2 \%$ and post $=69.6 \%$ ), does not have a bad opinion of himself (pre $=34.8 \%$ and post $=69.6 \%$ ), he would not like to be someone else ( $\mathrm{pre}=13$ and post $=47.8 \%$ ).

Family well-being reported an improvement after the application of Reiki, and when comparing the pre- and post-descriptive results of the family well-being variable, a considerable increase of this alternative therapy is observed when making a comparison between pre and post alcohol consumption of Reiki, it is shown through descriptive statistics that Reiki is effective to reduce alcohol consumption with respect to the dose of non-alcohol consumption (Pre $=26.1 \%$, Post $=100 \%$ ), as the young adult mentioned that the dose of nonalcohol consumption daily after the intervention was considerably low (Pre=34.8\%), Post=100\%). Regarding the consumption of 4 or more cigarettes per day, there was also a significant decrease after the intervention (Pre $=26.1 \%$, Post $=17.4 \%$ ), consumption of 2 to 3 cigarettes a week $(21.7 \%$, Post $=13) \%$ ), on the consumption of 1 to 10 packs of cigarettes per month, an important decrease was also reported (Pre $=47.8 \%$, Post $=34.8 \%$ ).

At the time of questioning the young adult about marijuana use, no variation was reported in the frequency of consumption in the last year, month and day, both in the pre-intervention and post-intervention data suggest that the young adult does not report the real consumption, due to social stigma about such addictive behavior.

When applying the t-test for a sample, we can observe the difference in means, the variables of self-esteem and family well-being in young adults. Where $\mathrm{P} \leq 0.000$, after raising a variable of discrete ratio to is observed a $\mathrm{p}$ take as an indicator the average values, this in order to give greater rigor to the intervention and to be able to take the average values of self-esteem and family well-being, with the purpose to verify that Reiki in young adults is very significant (Table 1). 
Table I Average values of the variables self-esteem and family well-being and consumption of alcohol, tobacco and marijuana

\begin{tabular}{llll} 
& Average and DE before & Average and DE after & Value of P \\
\hline Self esteem & $14.48 \pm 3.752$ & $11.91 \pm 3.315$ & $P \leq 0.000$ \\
Family welfare & $40.91 \pm 14.333$ & $49.6 I \pm 13.344$ & $P \leq 0.000$ \\
Consumption of alcohol & $9.65 \pm 8.96$ & 0 & $P \leq 0.000$ \\
Tobacco use & 5.0 & 5.0 & - \\
Marijuana use & 0 & 0 & - \\
\hline
\end{tabular}

In relation to the consumption of tobacco in a month, values of the median of 5 are obtained, so there is no difference in consumption before and after the intervention. In the case of marijuana consumption in a month, it was found according to the database that in one month there was no consumption so before and after there is no difference in relation to the intervention; therefore there is no value $\mathrm{p}$.

\section{Discussion}

Rogers raises in his theory non-invasive techniques to restore the well-being of the person, and mentions some therapies such as; the therapeutic touch, meditation, self-reflection. ${ }^{5}$

In the present study a significant difference was found after applying Reiki therapy in young adults; self-esteem increased significantly and improved family well-being, so it was shown that Reiki is effective for both study variables, these results agree with the results obtained by Ávila and Gómez in the metabolic control of type 2 diabetics, as it demonstrated that Reiki was able to reduce T/A (blood pressure) and glucose levels. The authors conclude that Reiki can influence the control of glucose and cholesterol. ${ }^{6}$

It is important to note that in both studies, it is shown that Reiki helps balance the altered energy field of a person, since in the postulates of Martha Rogers visualizes people with health problems as people with unbalanced energy fields, for lack of a harmonious interaction between his field and that of the environment, in this way with the intervention of the Reiki the resonance is extended restoring the inner balance.

When measuring alcohol consumption and tobacco consumption after applying Reiki, there was a $100 \%$ decrease in alcohol and tobacco with a difference of $34 \%$, these results reaffirm that alternative therapies are significant to modify some addictive behaviors; as shown by the work done by Ontiveros L \& Casique $\mathrm{L}^{7}$ called effectiveness of auriculotherapy as nursing care to reduce the use of marijuana and cocaine in young adults, since they obtained satisfactory results with the decrease in marijuana and cocaine use, which shows that alternative therapies are effective in addictive behaviors.

It is important to note that in this study there was no reported variation in the frequency of marijuana, since the sample did not report actual consumption due to the social stigma of said drug. ${ }^{7}$

To test the hypothesis, the t-test was applied to compare means for a sample, where the effectiveness of Reiki was shown to increase self- esteem, improve family well-being and decrease alcohol consumption in the young adult of the State of Colima $(\mathrm{P} \leq 0.000)$, for this reason the research hypothesis is accepted before these results.

\section{Conclusion}

When applying the Reiki program as nursing care, self-esteem increased, family welfare increased after therapy; when applying Reiki as nursing care in alcohol consumption, there were differences in the pre- and post-intervention, in cigarette consumption a month there was a significant difference in the pre- and post-intervention; no frequency variation was reported in the consumption of marijuana in the last year, month and day therefore in this variable it is not possible to affirm that Reiki is effective in the decrease in the consumption of marijuana.

When applying the t-test for a sample, a difference of significant mean is $\mathrm{P} \leq 0.000$, which indicates that Reiki as nursing $\leq$ observed with a value of $P$ care is effective to increase self-esteem and improve family well-being.

\section{Acknowledgments}

None.

\section{Conflicts of interest}

The authors declare there is no conflict of interest.

\section{References}

1. http://www1.paho.org/spanish/dpi/100/100feature24.htm

2. https://dialnet.unirioja.es/servlet/articulo? codigo $=111813$

3. https://www.wma.net/es/policies-post/declaracion-de-helsinki-de-laamm-principios-eticos-para-las-investigaciones-medicas-en-sereshumanos/

4. Roselli A, Cruz M. O adolescentes e o usos de drogas. Rev Bras Psiquiatr. 2000;22(Supl 11):32-36.

5. Wesley R. Teorías y Modelos de Enfermería. 2nd ed. México, DF: Editorial McGraw-Hill Interamericana S.A. de C.V; 1997:73-79.

6. http://www.medigraphic.com/pdfs/enfermeriaimss/eim-2010/eim102c pdf

7. http://pepsic.bvsalud.org/pdf/smad/v14n3/03.pdf 